\title{
Return to Capital and Foreign Direct Investment: A Cross-Country Perspective
}

\author{
John Vahaly \\ College of Business \\ University of Louisville \\ Louisville, KY 40292, USA \\ Nan-Ting Chou \\ College of Business \\ University of Louisville \\ Louisville, KY 40292, USA \\ Alexei Izyumov \\ College of Business \\ University of Louisville \\ Louisville, KY 40292, USA
}

\begin{abstract}
Using newly available data, the paper estimates aggregate macroeconomic rates of return (ROR) for 109 countries divided into highly developed (HDC), less developed (LDC), and transition economy (TEC) groups. We then analyze the connection between the ROR and cross-country capital flows as measured by foreign direct investment (FDI). For the period of 1994-2014, we find statistically significant links between all measures of ROR and inflows of FDI associated with the prevalence of "downhill" capital flows across the world.
\end{abstract}

JEL classifications: E22, E25, F21

Keywords: Return on capital, foreign direct investment, capital mobility

\section{Introduction}

Neoclassical theory posits that investment should go from countries where returns on capital are low to where they are high, as from developed to developing countries. ${ }^{1}$ Empirically, however, international investment is allocated mostly among developed countries while substantial amounts go from developing to developed countries, the so-called "uphill" capital flows (Lucas, 1990, Prasad et al., 2007; Gourinchas and Jeanne, 2013;Azemar and Desbordes, 2013; Eichengreen, et al., 2017).In the literature, this phenomenon, sometimes called "Lucas Paradox," is primarily explained by two hypotheses. Lucas himself (1990) and a number of other authors (Benhabib and Spiegel, 1994; Noorbakhsh et al, 2001; Wang and Wong, 2009; Kim and Park, 2013) attributed the paucity of richer-to-poorer countries capital flows to the shortage of capital complementarities in poorer countries, such as advanced technology and skilled labor. The alternative explanation emphasized capital flow frictions, mostly related to lower quality of institutions and higher investment risks in poorer countries (Gordon and Bovenberg, 1996; Reinhart and Rogoff, 2004; Alfaro et al., 2008, 2014). Lack of reliable crosscountry data on aggregate ROR deterred empirical analysis of these claims.

Recently, estimates of ROR were provided for a number of individual countries and groups of countries (European Central Bank, 2004;Bai et al., 2006; Udry and Anagol, 2006; Caselli and Feyrer, 2007; Mello, 2009; Ferreira, 2011; Chou et al., 2016). A large number of studies investigated the connection between international capital flows and other macroeconomic variables and institutional determinants such as trade openness, exchange rates, employment rights, or level of corruption (Obsfield, 1995; Chakrabarti, 2001; Obsfield and Taylor, 2004; Kinda, 2010; Aguiar and Amador, 2011; Gourinchas and Jeanne, 2013; Alfaro et al., 2014; Wood et al., 2016; Kechagia and Metaxas, 2018).

\footnotetext{
${ }^{1}$ In a related draft paper by Chou, N-T, Izyumov, A, and Vahaly, J., "Capital Profitability and Economic Growth,” studies the effects of the rate of return on capital on economic growth.
} 
However no study of which we are aware focused on investigating the connection between the aggregate profitability of capital and FDI flows. The main research question of this study concerns the link between FDI and the ROR. We hypothesize that in the recent period of globalization, integration of global financial markets, opening of post-communist countries, and significant improvement in business communications may have changed the patterns of international investment reversing the "uphill" capital flows. In a more open and transparent global economy, capital may find it easier to flow across countries in the expected direction--from lower to higher ROR.

To test this hypothesis, we investigate the relationship between cross-country FDI flows and capital profitability as represented by ROR. Using newly available data from the Penn World Table (PWT) 9.0 (2018), we estimate the pre-tax, after-tax, and tax- and risk-adjusted returns to the capital stock covering the 1994-2014 period for a sample of 109 countries. In 2014, these countries' GDP comprised over 95\% of global output. Using various measures of ROR, we analyze the connection between FDI and aggregate profitability in host countries.

The paper consists of five sections. Following this introduction, Section 2 presents the framework of analysis and data. Section 3 discusses estimates of ROR. Section 4 investigates the relationship between ROR and FDI. Section 5 concludes.

\section{Analytical framework and data}

To test the direction of cross-country capital flows, we investigate the relationship between the inflow of FDI and ROR:

$F D I_{i t}=f\left(R O R_{i t}, X_{i t}\right)$

Where $F D I_{i t}$ is foreign direct investment flow to country $i$ at time $t$ measured as a share of GDP; $R O R_{i t}$ is the macroeconomic return on capital in country $i$ at time $t$ as detailed below; $X_{i t}$ is a vector of host country's characteristics. Data on FDI flows are provided on a net basis and include all capital transactions between direct investors and their foreign affiliates: equity capital, reinvested earnings, and intra-company loans (World Bank, 2017). If the relationship between FDI and ROR is positive, capital flows from countries with low capital profitability to those with higher returns.

Aggregate ROR for a country is defined as:

$R O R=\square \square \nabla K_{n}$,

where $\square$ is income on capital (profits) and $K_{n}$ is the fixed capital stock, both measured in local currencies in current prices. This aggregate ROR can be represented as:

$$
R O R=\left(\square / Y_{n}\right)\left(Y_{n} / K_{n}\right)=\square\left(Y_{n} / K_{n}\right)
$$

Where $Y_{n}$ is nominal GDP, $\square$ is capital income share in GDP.

Data for capital income shares in GDP $(\square)$ are derived from labor income shares provided by the PWT 9.0 database(2016). The factor income shares of GDP in this database are estimated with adjustments for mixed sector income, which accounts for profits generated by non-incorporated enterprises.Capital stock data is also from PWT 9.0 (2016).

Estimates of ROR as defined in (3) provide a pre-tax measure of the aggregate ROR.We further adjust ROR for taxes and for risk. FDI sensitivity to taxation is demonstrated by considerable empirical evidence (King and Fullerton, 1984; Grubert and Mutti, 1991; Hines and Rice, 1994; Devereux et al., 2008; Becker et al., 2012; Egger and Raff, 2015).

\section{After-tax ROR is defined as:}

$$
\operatorname{ROR}_{i t}^{T}=\operatorname{ROR}_{i t}{ }^{*}\left(1-\square{ }_{i t}\right)
$$

Where $R O R_{i t}^{T}$ is the tax-adjusted ROR for country $i$ in year $t, \square_{i t}$ is the effective tax rate on profits. The effective corporate tax rates are provided by KPMG (2018).

The additional adjustment to ROR takes into account investment risk in host countries. The role of risk in FDI allocation is documented in many studies (e.g. Gordon and Bovenberg, 1996; Reinhart and Rogoff, 2004; Alfaro et al., 2008, 2014). Adjusting after-tax ROR to reflect country-specific risk yields:

$$
\operatorname{ROR}_{i t}^{T R}=\operatorname{ROR}_{i \mathrm{t}}{ }^{*}(1-\square i t)-\square_{i t}
$$


Where $R O R^{T R}{ }_{i t}$ is tax- and risk-adjusted ROR for country $i$ in year $t$, and $\square_{i t}$ is the estimated country risk premium above the benchmark. The country risk premiums are obtained from Damodaran (2018), where premiums are estimated based on sovereign default spreads and the volatility of national equity markets.

The benchmark countries are countries with the lowest risk premium for eachsample year (e.g. United States, Canada, and Switzerland). The risk premium data starts in year 2000. In addition to country-specific ROR, we computed capital-weighted average ROR for developing, developed, and transition groups of countries. The capital-weighted average ROR for groups of countries, $R O R_{t}$, was computed as:

$$
R O R_{t}=\sum_{i=1}^{N} R_{O} O R_{i t} *\left(K_{i t} / \sum_{i=1}^{N} K_{i t}\right)
$$

Where $R O R_{i t}$ is the ROR for country $i$ in year t, $K_{i t}$ is the capital stock of country $i$ in year $t$, and $N$ the number of countries included in the group.

\section{Estimates of ROR}

Figures 1 through 3 show the average capital profitability for developing, developed, and transition countries. Figure 1 presents pre-tax ROR and indicates a downward trend for LDC and HDC and no discernable trend for TEC. Capital profitability for LDC is higher than for HDC and TEC. For TEC, the profitability was lower than in HDC before 2000 but consistently higher afterwards. The average after-tax ROR for the three groups are shown in Figure 2. For most of the sample period, capital profitability for LDC is the highest and the ROR for HDC is the lowest with the TEC group in between. Tax- and risk-adjusted ROR shown in Figure 3 indicate a general decline between 2000 and 2014 for developed countries but no clear trend for LDC and TEC. The fully-adjusted ROR for LDC and TEC were higher than in HDC for most years and tended to converge after the global recession of 2008-2009.

Figure 1Capital-weighted pre-tax ROR by country group

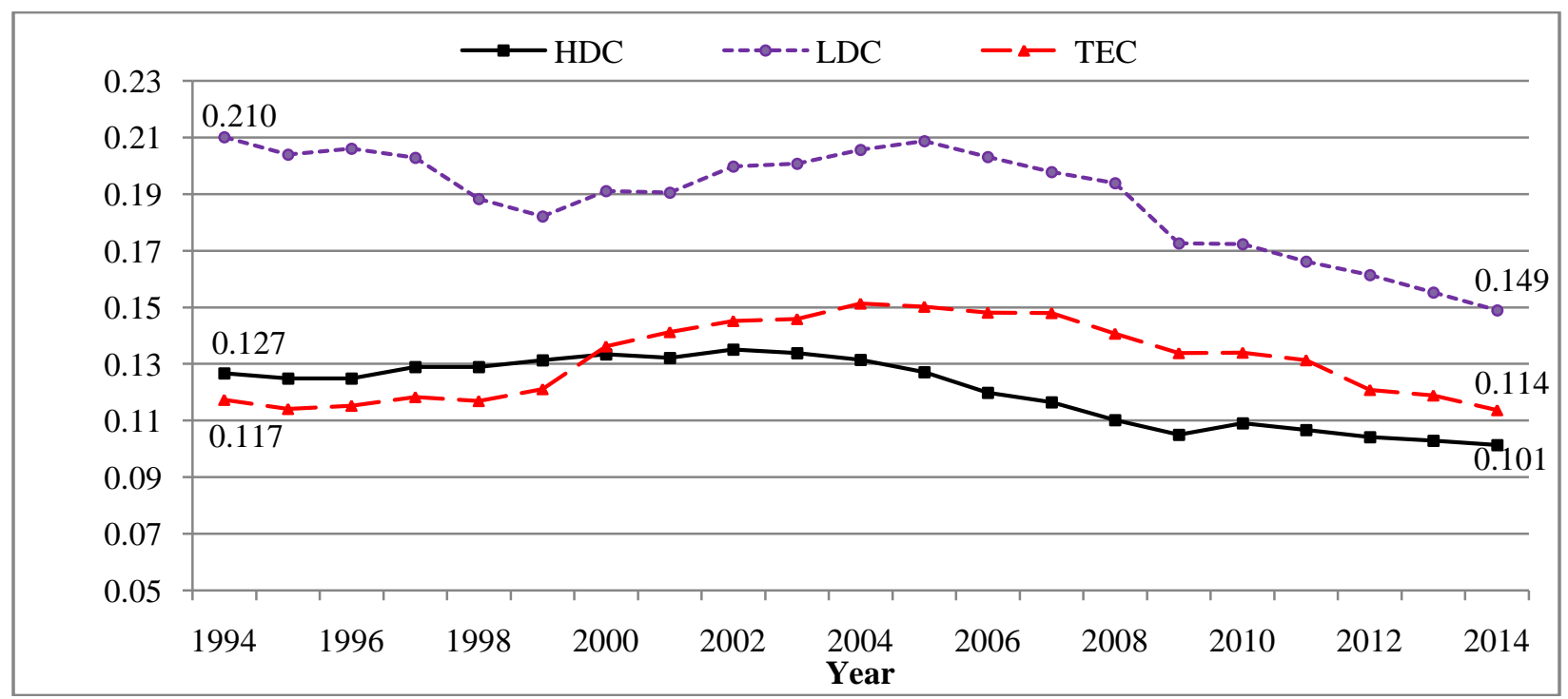

(Source: Authors' calculations) 


\section{Figure2Capital-weighted after-tax ROR by country group}

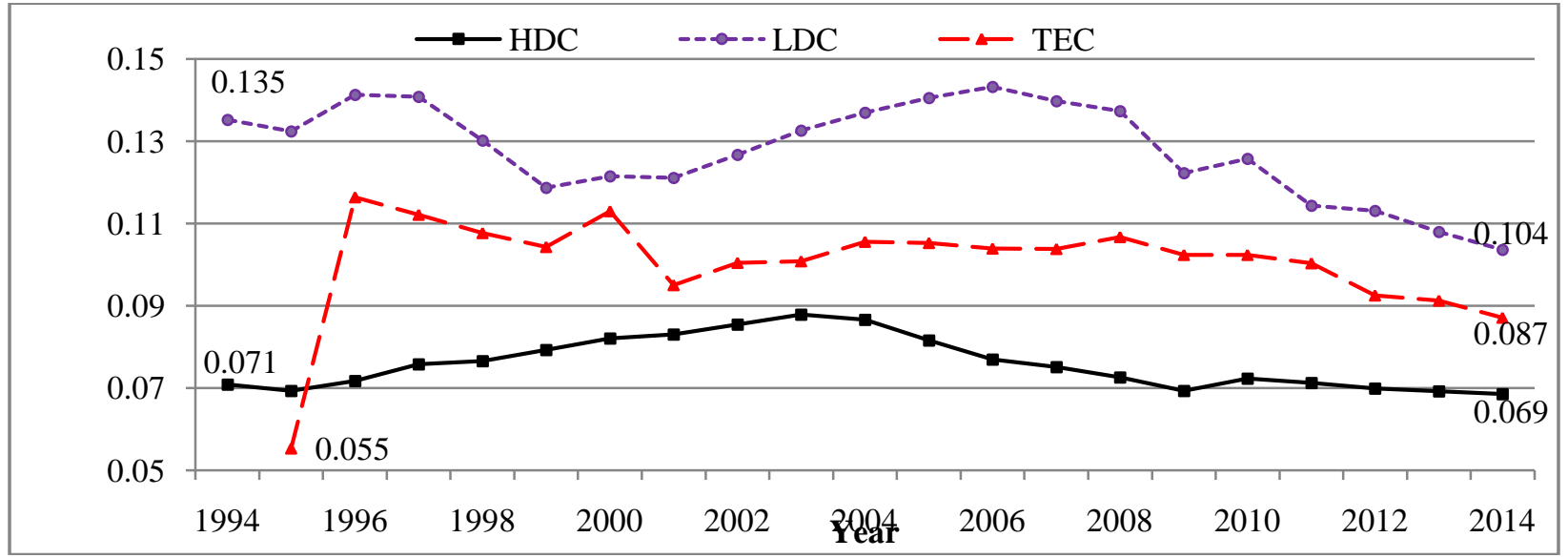

(Source: Authors' calculations)

Figure3Capital weighted tax- and risk- adjusted ROR by country type

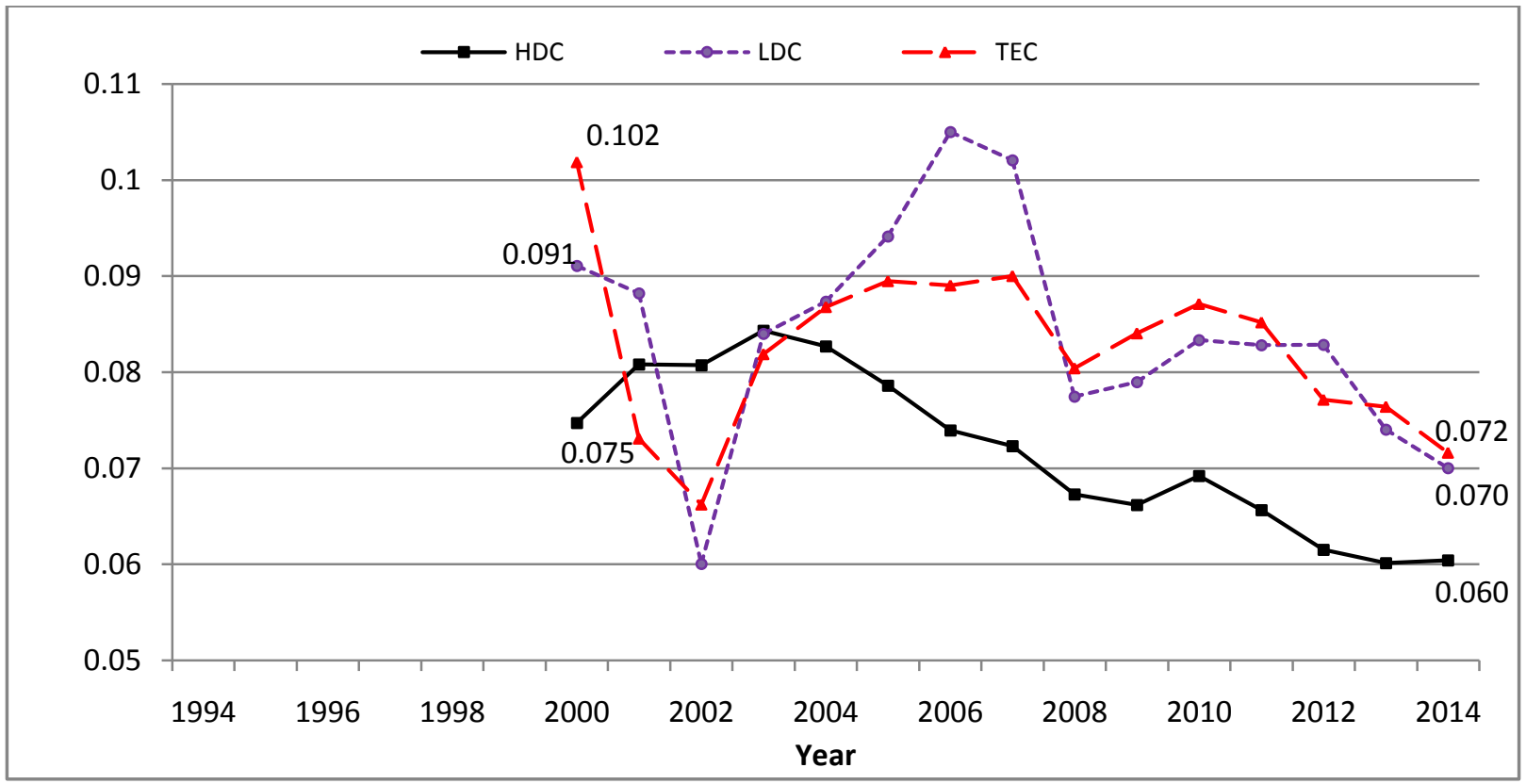

(Source: Authors' calculations)

Overall, capital profitability in LDC and TEC was higher than in HDC for all of its measures for most years. Our estimates of ROR generally match the results in the literature, where most cross-country studies reported ROR to be consistently higher in less developed economies (Bigsten, 2000; Banerjee and Duflo, 2005; Izyumov and Alterman, 2005;Bai et al., 2006; Lu and Gao, 2009; Udry and Anagol, 2006; Chou et al., 2016).

\section{ROR and FDI: analysis and discussion}

To test the relationship between FDI and macroeconomic profitability, we estimate a reduced-form model that links the ROR levels to FDI inflows. The regression is specified as:

$F D I_{i t}=\gamma_{\mathrm{t}}+\theta_{y}+\square_{1} R O R_{i t}+\square_{2} X_{i t}+\square_{i t}$

Where $F D I_{i t}$ is foreign direct investment flow to country $i$ at time $t$ measured as a share of GDP. Equation (7) includes year and country-type fixed effects represented by $\gamma$ and $\theta$ respectively. 
$R O R_{i t}$ denotes a specific measure of the return on capital as developed in (2) - (5). The vector $X$ represents characteristics of the host countries and $\square \square_{i t}$ is the error term.

The vector of control variables includes trade openness, secondary education enrollment ratio, and the price level of domestic capital stock. Trade openness is defined as the ratio of the sum of imports and exports to GDP. Trade openness as an important determinant of the FDI is confirmed by a number of recent studies covering developing and post-communist economies (Tintin, 2013; Seyoum et al., 2014; Thangavelu and Narjoko, 2014). Similarly, other studies (Culem, 1988; Mina, 2007; Antras and Caballero, 2009; Kechagia and Metaxa, 2018) found that higher levels of trade openness attract FDI in a wide variety of developing and developed economies.

The secondary education enrollment ratio is the ratio of total secondary education enrollment to the total secondary school-age population. It serves as a proxy for the skills of the labor force (Borghans, et al, 2001). Given that labor skills are complements to capital, the secondary enrollment ratio is expected to be positively related to FDI inflows (Lucas, 1990; Noorbakhsh, et al, 2001; Suliman and Mollick, 2009; Kim and Park, 2013). The price level of the domestic capital stock is normalized to the US price level in 2011. This variable reflects the price of the capital stock in the host country relative to that of the US. FDI inflows are expected to be higher in countries with lower capital prices.

FDI inflows, trade openness, and secondary education enrollment data are computed using data from the World Bank's World Development Indicators (2017). Data for the capital stock price is from PWT 9.0 (2016).Descriptive statistics for variables included in the analysis are presented in Table 1.

Table (1) Descriptive statistics

\begin{tabular}{|c|c|c|c|c|c|}
\hline Variables & $\begin{array}{l}\text { Number } \\
\text { observations }\end{array}$ & of $\quad$ Mean & $\begin{array}{l}\text { Standard } \\
\text { deviation }\end{array}$ & Minimum & Maximum \\
\hline FDI percentage of GDP & 1,065 & 4.172 & 5.720 & -16.091 & 50.785 \\
\hline Return on capital (ROR) & 1,065 & 0.155 & 0.064 & 0.048 & 0.438 \\
\hline Tax rates & 1,065 & 0.283 & 0.082 & 0.000 & 0.590 \\
\hline Risk premium & 823 & 0.077 & 0.031 & 0.045 & 0.208 \\
\hline After tax ROR & 1,065 & 0.111 & 0.049 & 0.039 & 0.336 \\
\hline Risk- and tax-adjusted ROR & 823 & 0.086 & 0.052 & -0.099 & 0.312 \\
\hline Trade openness & 1,065 & 0.696 & 0.524 & 0.075 & 4.615 \\
\hline $\begin{array}{l}\text { Gross enrolment ratio, secondary } \\
\text { education }(\%)\end{array}$ & 1,065 & 92.93 & 21.05 & 15.29 & 163.10 \\
\hline $\begin{array}{l}\text { Price level of the capital stock (price } \\
\text { level of USA in 2011=1) }\end{array}$ & 1,065 & 0.651 & 0.302 & 0.137 & 1.686 \\
\hline
\end{tabular}

(Source: Authors' calculations)

Due to data availability, there are 68 countries included in the regression analysis, covering the sample period of 1994 to 2014. There are missing data for some countries over some years, thus it is an unbalanced panel data. We use General Linear Models (GLM) analysis with year and country-type fixed effects.

Table 2 shows the regression results. All model specifications include three host country characteristic variables: trade openness, secondary education enrollment ratio, the price of the capital stock, and the year and country-type fixed effects. Model 1 uses pre-tax ROR as a proxy for capital profitability. Model 2 adds the corporate tax rate to Model 1. Pre-tax ROR, tax rate, and risk premium are included as explanatory variables in Model 3.Model 4 replace the pre-tax ROR in Model 1 with after-tax ROR. Model 5 adds risk premium to Model 4. The tax- and risk-adjusted ROR is included in Model 6. 
Table (2) Effects of ROR on FDI inflows (dependent variable: FDI percentage of GDP)

\begin{tabular}{|c|c|c|c|c|c|c|}
\hline Independent variables & Model 1 & Model 2 & Model 3 & Model 4 & Model 5 & Model 6 \\
\hline $\begin{array}{l}\text { Return on capital } \\
\text { (ROR) }\end{array}$ & $\begin{array}{l}11.05 * * * \\
(3.73)\end{array}$ & $\begin{array}{l}10.16^{* * * *} \\
(3.39)\end{array}$ & $\begin{array}{l}11.98 * * * \\
(3.24)\end{array}$ & & & \\
\hline After-tax ROR & & & & $\begin{array}{l}14.76^{* * *} \\
(4.02)\end{array}$ & $\begin{array}{l}15.58 \text { *** } \\
(3.47)\end{array}$ & \\
\hline $\begin{array}{l}\text { Tax- and risk-adjusted } \\
\text { ROR }\end{array}$ & & & & & & $\begin{array}{l}8.41 * * \\
(2.31)\end{array}$ \\
\hline Tax rates & & $\begin{array}{l}-4.48 * \\
(-1.91)\end{array}$ & $\begin{array}{l}-2.26 \\
(-0.72)\end{array}$ & & & \\
\hline Risk premium & & & $\begin{array}{l}9.61 \\
(1.26)\end{array}$ & & $\begin{array}{l}9.71 \\
(1.28)\end{array}$ & \\
\hline Trade openness & $\begin{array}{l}6.25 * * * \\
(19.76)\end{array}$ & $\begin{array}{l}6.04 * * * \\
(18.06)\end{array}$ & $\begin{array}{l}6.61 * * * \\
(16.88)\end{array}$ & $\begin{array}{l}6.15^{* * * *} \\
(19.43)\end{array}$ & $\begin{array}{l}6.61 * * * \\
(18.31)\end{array}$ & $\begin{array}{l}6.48 * * * \\
(18.04)\end{array}$ \\
\hline $\begin{array}{l}\text { Secondary education } \\
\text { enrollment ratio }\end{array}$ & $\begin{array}{l}0.03^{* * *} \\
(3.18)\end{array}$ & $\begin{array}{l}0.03 * * * \\
(2.93)\end{array}$ & $\begin{array}{l}0.04 * * * \\
(2.74)\end{array}$ & $\begin{array}{l}0.03 * * * \\
(3.06)\end{array}$ & $\begin{array}{l}0.04 * * * \\
(2.72)\end{array}$ & $\begin{array}{l}0.04 * * * \\
(2.57)\end{array}$ \\
\hline Price level of capital & $\begin{array}{l}-2.56 * * \\
(-3.00)\end{array}$ & $\begin{array}{l}-2.45 * * * \\
(-2.87)\end{array}$ & $\begin{array}{l}-2.33 * * \\
(-2.25)\end{array}$ & $\begin{array}{l}-2.51 * * * \\
(-2.95)\end{array}$ & $\begin{array}{l}-2.28 * * * \\
(-2.21)\end{array}$ & $\begin{array}{l}-2.42 * * \\
(-2.34)\end{array}$ \\
\hline Number of obs. & 1065 & 1065 & 823 & 1065 & 823 & 823 \\
\hline Adjusted R-square & 0.38 & 0.38 & 0.40 & 0.38 & 0.40 & 0.39 \\
\hline
\end{tabular}

Notes: Coefficient from GLM models are reported. All specifications control year and country-type fixed effects. Asterisks denote statistical significance as follows: $* * *$ p-value $\leq 0.01 ; * * 0.01<$ p-value $\leq 0.05$; and $* 0.05<\mathrm{p}$ value $\leq 0.10$.

(Source: Authors' calculations.)

The parameter of interest is $\square_{1}$ in equation (7) which captures the effects of various measures of ROR on a country's FDI inflows. For all six models, estimates of $\square_{l}$ are positive and significant. This supports the view that the level of FDI flows is positively related to ROR. For example, in Model 6, for every one percentage-point increase of tax-and risk adjusted ROR, the FDI to GDP ratio increases 0.08 percent.

The results confirm that trade openness is positively related to FDI inflows for all six specifications supporting the complementarily between trade openness and capital mobility (Kravis and Lipsey, 1982; Culem, 1988; Antras and Caballero, 2009; Thangavelu and Narjoko, 2014). The quality of human capital as measured by the secondary education enrollment ratio is positive and significant in all models. This demonstrates that FDI inflows are positively affected by the quality of complementary labor inputs (Lucas, 1990; Benhabib and Spiegel, 1994; Noorbakhsh et al, 2001; Wang and Wong, 2009; Azemar and Desfordes, 2013; Kim and Park, 2013). As expected, the higher price level of capital proved to be an important deterrent of FDI inflows. The coefficients of the price of capital are negative and significant for all models. Overall, our results provide evidence that FDI inflows are positively related to macroeconomic ROR.

\section{Conclusions}

The phenomenon of international investment not following profitability and going "uphill" - from poorer to richer countries, has been a long-standing pattern in the global economy. In this paper, we hypothesize that in the last twenty years, rapid integration of financial markets along with the opening of post-communist economies may have changed this pattern. Using recently available data, we estimated the macroeconomic capital profitability for 109 developing, developed, and transition economy countries. Our analysis found a positive and statistically significant association between various measures of macroeconomic profitability and FDI. These findings are consistent with the predictions of economic theory. The positive connection between capital flows and ROR during the recent period of globalization possibly indicates the dominance of downhill investment flows as the new norm.

In the long run, if capital continues to flow to higher ROR countries, capital profitability should converge toa global average. The existing differences between national ROR continue to imply underinvestment in the majority of developing and transition countries. 


\section{References}

Aguiar, M., \& Amador, M. (2011).Growth in the shadow of expropriation. Quarterly Journal of Economics, 126, 651697.

Alfaro, L., Kalemli-Ozcan,S., \&Volosovych,V. (2008). Why doesn'tcapital flow from rich to poor countries? An empirical investigation. Review of Economics and Statistics, 90, 347-368.

(2014) Sovereigns, upstream capital flows, and global imbalances. Journal of the European Economic Association, 12, 1240-1284.

Antras, P.,\& Caballero,R. (2009). Trade and capital flows: a financial frictions perspective. Journal of Political Economy, 117, 701-744.

Azémar, C., \&Desbordes, R. (2013).Has the Lucas Paradox been fully explained? Economics Letters, 121, 183-187.

Bai, C., Hsieh, C-T.,\& Qian, Y. (2006).The return to capital in China.Brookings Papers on Economic Activity, 2, 61100.

Banerjee,A.,\&Duflo,E. (2005).Growth theory through the lens of development economics. Handbook of Development Economics,Amsterdam: Elsevier, 473-552.

Becker, J., Fuest, C., \& Riedel, N. (2012). Corporate tax effects on the quality and quantity of fdi. European Economic Review, 56, 1495-1511.

Benhabib, J.,\& Spiegel, M. (1994).The role of human capital in economic development: evidence from aggregate cross-country data.Journal of Monetary Economics, 34, 143-73.

Bigsten, A. (2000).Rates of return on physical and human capital in Africa's manufacturing sector. Economic Development and Cultural Change, 48, 801-27.

Borghans, L., Green, F., \& Mayhew, K. (2001). Skills measurement and economic analysis: an introduction. Oxford Economic Papers, 53, 375-384.

Caselli, F., \& Feyrer, J. (2007). The marginal product of capital. Quarterly Journal of Economics, 122, 535-568.

Chakrabarti, A. (2001).The determinants of foreign direct investments: sensitivity analyses of cross-country regressions.Kyklos,54, 89-114.

ChouNT., Izyumov A., \&Vahaly J. (2016). Rates of return on capital around the world: are they converging? Cambridge Journal of Economics, 40, 1149-1166.

Culem, C. G. (1988). The locational determinants of direct investments among industrialized countries.European Economic Review, 32, 885-904.

Damodaran, A., (2018).Equity risk premiums (ERP): determinants, estimation and implications.[Online] Available:http://pages.stern.nyu.edu/ adamodar/(2018)

Devereux,M.P., Lockwood,B., \&Redoano, M. (2008).Do countries compete over corporate tax rates? Journal of Public Economics, 92, 1210-1235.

Egger, P., \&Raff, H. (2015). Tax rate and tax base competition for foreign direct investment. International Taxation and Public Finance,22, 777-810.

Eichengreen, B., Gupta, B., \&Masetti, O. (2017). Are capital flows fickle? World Bank Policy Research Paper, 7972. Washington, DC: World Bank.

European Central Bank (2004).Measuring and Analyzing Profit Developments in the Euro Area, 63-73.

Ferreira,A.L. (2011).On the differences between the marginal product of capital across countries. Manchester School, $79,455-79$.

Gordon, R., \&Bovenberg,A.L. (1996).Why is capital so immobile internationally? Possible explanations and implications for capital income taxation. American Economic Review, 86, 1057-1075.

Gourinchas, P-O., \& Jeanne, O. (2013). Capital flows to developing countries: the allocation puzzle.Review of Economic Studies, 80, 1484-1515.

Grubert, H., \&Mutti, J. (1991). Taxes, tariffs and transfer pricing in multinational corporate decision making. Review of Economics and Statistics, 73, 285-293.

Hines, J.R., \& Rice,E.M. (1994). Fiscal paradise: foreign tax havens and American business. Quarterly Journal of Economics, 109, 149-182.

Izyumov, A.,\&Alterman, S. (2005). The general rate of profit in a new market economy. Review of Radical Political Economy, 37, 476-93.

Izyumov, A.\& Vahaly,J. (2015).Income shares revisited. Review of Income and Wealth, 61, 179-188.

Kechagia, P.,\&Metaxas, T. (2018). Sixty years of FDI empirical research: review, comparison and critique.The Journal of Developing Areas, 52, 169-181. 
Kim, J., \& Park, J. (2013). Foreign direct investment and country-specific human capital. Economic Inquiry, 51, 198210.

King, M.A., \& Fullerton, D. (1984).The Taxation of Income from Capital. Chicago: University of Chicago Press.

Kravis,I.B., \&Lipsey,R.E. (1982). The location of overseas production and production for export by U.S. multinational firms.Journal of International Economics, 12, 201-223.

Lucas, R. (1990). Why does capital flow from rich to poor countries? American Economic Review,80, 92-96.

Mello, M. (2009).Estimates of marginal product of capital, 1970-2000.The B.E. Journal of Macroeconomics, 9, 1-28.

Obsfield, M. (1995). International capital mobility in the 1990s. In P. Kenen (Ed.),Understanding Interdependence: the Macroeconomics of the Open Economy. Princeton, NJ: Princeton University Press.

Obsfield, M., \& Taylor, A. (2004).Global Capital Markets Integration, Crisis, and Growth. Cambridge: Cambridge University Press.

Penn World Table 9.0. (2018).[Online] Available: http://www.rug.nl/ggdc/ (2018)

Prasad,E.S., Rajan, R.G., \& Subramanian, A. (2007). Foreign capital and economic growth. Brookings Papers on Economic Activity, 1, 153-209.

Reinhart, C.,\& Rogoff, K. (2004). Serial default and the 'paradox' of rich-to-poor capital flows. American Economic Review, 94, 53-58.

Seyoum, M., Wu, R., \&Lin, J. (2014). Foreign direct investment and trade openness in sub- Saharan economies: A panel data granger causality analysis.South African Journal of Economics, 82, 402-421.

Suliman, A.H., \&Mollick,A.V. (2009).Human capital development, war and foreign investment in sub-Saharan Africa. Oxford Development Studies, 37, 47-61.

Thangavelu,S.M., \&Narjoko, D. (2014). Human capital, FTAs and foreign direct investments flows into ASEAN.Journal of Asian Economics, 35, 65-76.

Tintin, C. (2013). The determinants of foreign direct investment inflows in the Central and Eastern European Countries: The importance of institutions.Communist and Post - Communist Studies, 46, 287-298.Udry, C.,\&Anagol, S. (2006). The return to capital in Ghana.American Economic Review. 96, 388-393.

Wang, M., \& Wong, M.C. (2009).Foreign direct investment and economic growth: the growth accounting perspective. Economic Inquiry, 47, 701-710.

World Bank (2017)World Development Indicators. Washington, DC: World Bank. [Online] Available: data.worldbank.org/data-catalog/world-development-indicators (2018)

\section{Appendix}

Appendix Table A1. List of countries

\begin{tabular}{|c|c|c|c|}
\hline \multirow[b]{2}{*}{$H D C$} & \multirow{2}{*}{\multicolumn{2}{|c|}{$L D C$}} & \multirow{2}{*}{$T E C$} \\
\hline & & & \\
\hline Australia & Argentina & Mexico & Armenia \\
\hline Austria & Bolivia & Mauritius & Bulgaria \\
\hline Belgium & Brazil & Malaysia & Bosnia and Herzegovina \\
\hline Canada & Botswana & Namibia & Belarus \\
\hline Switzerland & Chile & Oman & China \\
\hline Germany & Colombia & Panama & Czech Republic \\
\hline Denmark & Costa Rica & Peru & Estonia \\
\hline Spain & Dominican Republic & Philippines & Georgia \\
\hline Finland & Ecuador & Paraguay & Croatia \\
\hline France & Guatemala & Saudi Arabia & Hungary \\
\hline United Kingdom & Honduras & Senegal & Kazakhstan \\
\hline Greece & Indonesia & Thailand & Lithuania \\
\hline Hong Kong & India & Trinidad & Latvia \\
\hline Ireland & Iran & Tunisia & Macedonia \\
\hline Iceland & Jordan & Turkey & Poland \\
\hline Israel & Kenya & Tanzania & Romania \\
\hline Italy & Lebanon & Uruguay & Russia \\
\hline Japan & Sri Lanka & Venezuela & Serbia \\
\hline Korea, Republic of & Morocco & South Africa & Slovak Republic \\
\hline Norway & & & Slovenia \\
\hline New Zealand & & & Ukraine \\
\hline \multicolumn{4}{|l|}{ Portugal } \\
\hline \multicolumn{4}{|l|}{ Singapore } \\
\hline Sweden & & & \\
\hline
\end{tabular}

